\title{
The Maternity Leave and Cash Benefit Payment System for Readymade Garment (RMG) Sector of Bangladesh
}

\author{
Salma Akter \\ BRAC IED (Institute of Education and Development) BRAC University, BANGLADESH \\ *(alma.pa.ju@gmail.com)
}

This journal is licensed under a Creative Commons Attribution-Noncommercial 4.0 International License (CC-BY-NC).

Articles can be read and shared for noncommercial purposes under the following conditions:

- BY: Attribution must be given to the original source (Attribution)

- NC: Works may not be used for commercial purposes (Noncommercial)

This license lets others remix, tweak, and build upon your work non-commercially, and although their new works must also acknowledge you and be non-commercial, they don't have to license their derivative works on the same terms. License Deed Link: http://creativecommons.org/licenses/by-nc/4.0/

Legal Code Link: http://creativecommons.org/licenses/by-nc/4.0/legalcode

$A B C$ Research Alert uses the CC BY-NC to protect the author's work from misuse.

\section{Abstract}

Maternity leave means the period of paid absence from work. This type of leave is allowed to a mother before and after the birth of a child. Naturally, the term maternity benefit is applied in case of working women. Mostly, it is related to readymade garment (RDM). It indicates the payment made to a woman for giving birth of a child. The duration of maternity leave for female worker in RMG sector of Bangladesh is 4 months (16 weeks) according to Labor Act 2006. The purpose of this study is to show the application of RMG sector's maternity leave and to assess the level of cash benefit payment for maternity leave. The main purpose of this study is to show the discrimination between two kinds of factories (foreign owned and local owned) about the proper application of rules and Act. The information collected from those who are experienced to take maternity leave and recently take the leave and also who are preparing for the leave.

Frequency distribution has been used on the data extracted from female worker who have experience maternity leave and cash benefit payment. The result of this study is that there are two kinds of RMG sectors situations: one is called foreigner owned factory and another one is Bangali factory (local owner). Evidently, $60 \%$ get the cash payment with two terms before $\&$ after child born and $100 \%$ get the maternity leave. So, this paper will discuss about the differences of facilities, job security, cash payment, others opportunities for female in RMG sector.

\section{Keywords}

RMG, maternity leave, cash payment, job security, child care, discrimination, competition.

"Without any blood sacrifice; we (women in RMG sector) could not get these opportunities" - Lucky: an eight years work experienced in this sector, talking about the maternity leave.

\section{INTRODUCTION}

Bangladesh has great fame for Muslim and jamdani cloth but only for royals in British period. After British era Bangladesh start new phenomena with organized garment industry. Baishakhi Garment was the first organized garment factory in 1977. I n this world Bangladesh is accounted as third world country. We have two large economic earning sources. First one is agriculture and another one is industry. Industrial sector mainly has got a greater facet than any other sector in terms of growth and foreign exchange earnings. In our RMG sector, the role of women is most important because $85 \%$ of 
garment workers are female. These females are mostly belongs to village and they are almost in low and no educational category.

In our country, the RMG sector having about 5100 factories and 10 million people directly or in directly depend on it. There are many problems in RMG sector which have to face women as a worker. Like the recruitment process, job security, irregular wage payment, and sexual harassment, force to do overtime work, maternity leave, difficulties to form a labor union and the social problem, domestic problem are also included. The Bangladesh government announced 'Bangladesh Labor Rules" which was published in September 15, 2015 after the RANA PLAZA collapse and TAZRIN GARMENT fire incident for ensuring the security for workers. There have many paper and article related to violation of rights of female worker in RMG sector. But the imbalance application of rules and laws for maternity leave and payment between Bengali (local owned) and foreign owned factories is not concern before.

\section{History of starting RMG sector in Bangladesh}

Bangladesh had a great history about Muslim and jamdani cloth in British era. After this era, these cloths were destroyed his fame. There was only individual tailor who made cloth and provide fabric for domestic purpose. After 1970's the organized export-oriented garment was established.

\begin{tabular}{|c|c|}
\hline Year & Name of garments \\
\hline 1977 & Baishakhi garment \\
\hline 1978 & Reaz, Paris, Jewel garment \\
\hline 1979 & Desh garment \\
\hline 1980 & Trexim Ltd \\
\hline
\end{tabular}

Table 1: History of Starting RMG sector in Bangladesh

*Source: history of garment sector in Bangladesh by Md. Fouad Hosain

\section{OBJECTIVE OF THE STUDY}

The objective of this study is to find out the real application of the rules that was published by the government. The specific objectives are following:

- To show the real application of the rules about maternity leave in RMG sector.

- To show the comparison about the application between foreign and local owned factories.

\section{Research question}

The research question for this paper is given below:

1. Do you have experienced about getting a leave for maternity purpose? yes/no

2. How do get the payment and the facilities about getting maternity leave?

3. Are you satisfied about how they (factory owner) treat you for maternity leave and payment?

For this paper, here different types of questions have been asked; open ended, close ended yes/no, descriptive questions.

\section{LITERATURE REVIEW}

"Ready-made Garment of Bangladesh: it's contribution and challenges towards development"- by M. Saiful Islam, Md Abdur Rakib, Atm Adnan discuss about the overall situation in RMG sector. They show the problem about previous years incident and also shows the contribution in GDP of Bangladesh. "Right of women workers in the Readymade garment (RMG) sector of Bangladesh: Law and practice" 
- by Md Abdur Rhim Mia; he discusses about violation of the rights of women workers. He also describes that all Garment industry of our country is a formal sector, but female workers are treated as in formal employees. "Female RMG worker: Economic contribution in Bangladesh" - by Dr. M. Habibur Rahman, Sayeed Ahmed Siddiqui; in their paper, they discuss about the contribution of female worker in RMG sector as well as the contribution to the national economy. "Labor unrest and Bangladesh Labor Act 2006: A study on Readymade Garment Factories in Gazipur"- by Mustafa Kamal, Mohammed Masum Billah, Sanida Hossain; they discuss about the relation between implementation of Bangladesh Labor Act 2006 and unrest. Their study reveals that employee's wages and payment is the most significantly correlated factor to labor unrest. This paper will discuss how management system of maternity leave and payment is work in real life practice. For this purpose, almost 20 Garment factories female worker's interview has been collected from the field level.

\section{RESEARCH METHODOLOGY}

In this paper, quantitative and qualitative research methodology has been used. For this paper, two types of data have been collected. The primary data was collected from female interviewers those have experience about maternity leave and those they have not. The secondary data was collected from the Wikipedia and RMG sector related articles, publications. In this study the variables are: a) duration of leave b) payment c) child care system after the child birth d) job security e) extra facilities: like getting extra medical facilities f) working time in pregnancy time. The steps of data collection are given below:

Step 1: The primary data was collected from mostly in Savar area.

Step 2: The questionnaire prepares according to survey topic gather idea from related articles.

Step 3: Data was collected based on questionnaire, data from variables which was collected from almost 20 garment factories workers.

Step 4: data was analysis with time series, frequency distribution through personal computer.

\section{DATA ANALYSIS}

In data analyzing process, here used two kinds of information. First one is the female workers ratio in RMG sector of Bangladesh. In this figure shows that 2014, out of 4 million manpower employed in garments industries, 3.20 million are female (80\%). The second one is the foreign and local investor-owned factories facilities those are given for female worker.

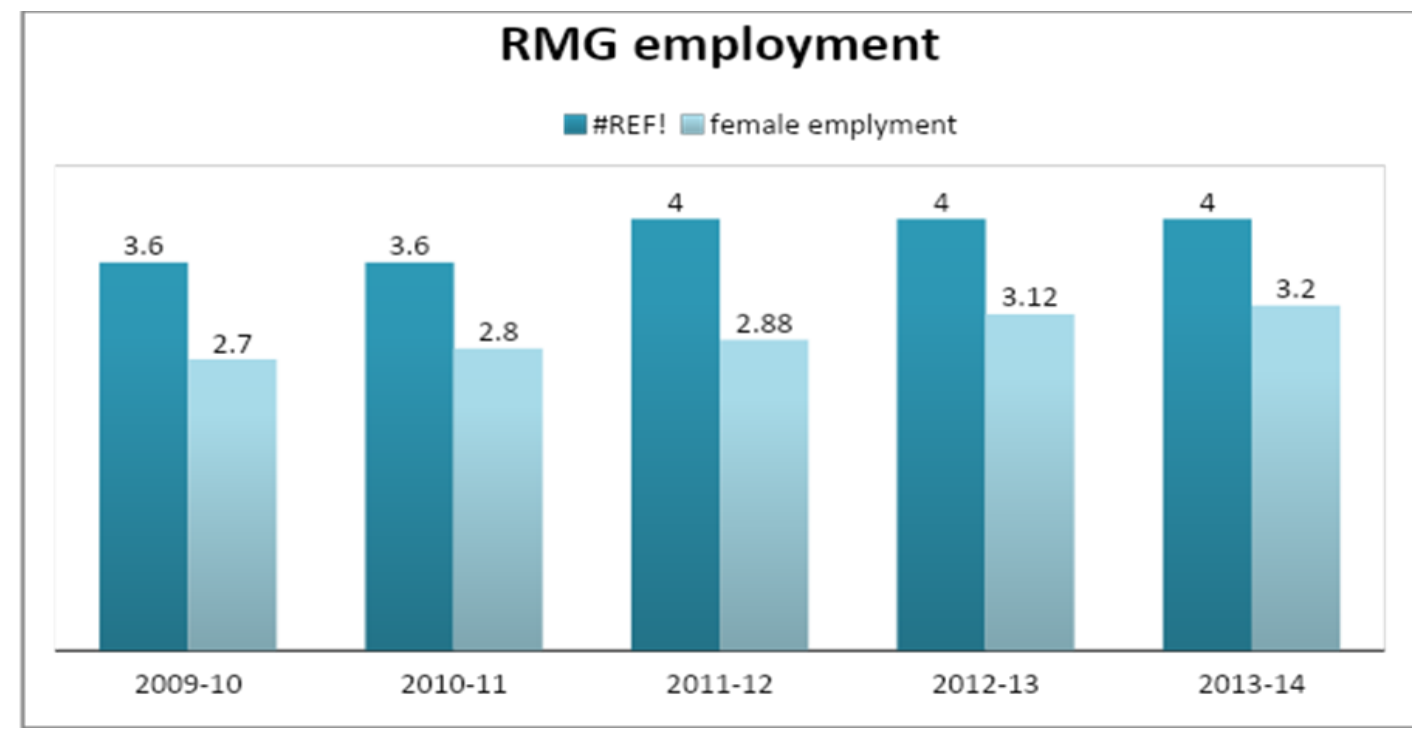

Figure 1: **First kind of information about ratio of female worker in RMG sector *Source: BGMEA

In this figure it is shows that the total employment and female employment. In 2009-10, total employment was 3.6 and female employment 2.7. In 2010-11, female employment increases 2.8 . The 
rest years total employment rate was same 4 and female employment rate increase gradually $2.88,3.12$, 3.2 .

\section{The comparison situation between local and foreign owned factories}

\begin{tabular}{|l|l|l|l|l|}
\hline Facilities & $\begin{array}{l}\text { Foreign owned } \\
\text { factories }\end{array}$ & Local owned factories & Average ratio & Description \\
\hline $\begin{array}{l}\text { 1.Duration of } \\
\text { leave }\end{array}$ & $\begin{array}{l}4 \text { months } \\
100 \%\end{array}$ & $\begin{array}{l}\text { Mostly 3 } \\
\text { Months 90\% }\end{array}$ & $\begin{array}{l}100-90=10 \% \\
95-5=90 \%\end{array}$ & $\begin{array}{l}10 \% \text { get proper leave } \\
\text { Opportunity 90\% do not get }\end{array}$ \\
\hline 2. Payment & $\begin{array}{l}\text { Advanced payment } \\
100 \%\end{array}$ & $\begin{array}{l}\text { months before and 2 } \\
\text { months after leaving 50\% }\end{array}$ & $\begin{array}{l}100-50=50 \% \\
95-50=45 \%\end{array}$ & $\begin{array}{l}50 \% \text { do not get advanced } \\
\text { payment 45\% get }\end{array}$ \\
\hline $\begin{array}{l}\text { 3. Child care sys- } \\
\text { tem afterbirth }\end{array}$ & $\begin{array}{l}\text { Ensure a child } \\
\text { care place } \\
100 \%\end{array}$ & $\begin{array}{l}\text { Not ensured in all fac- } \\
\text { tories } 80 \%\end{array}$ & $\begin{array}{l}100-80=20 \% \\
95-80=15 \%\end{array}$ & $\begin{array}{l}20 \% \text { get child care } \\
\text { facilities } 15 \% \text { do } \\
\text { not get }\end{array}$ \\
\hline $\begin{array}{l}\text { 4.Job secu- } \\
\text { rity }\end{array}$ & $\begin{array}{l}\text { Fully secured } \\
100 \%\end{array}$ & $\begin{array}{l}\text { Fully secured } \\
100 \%\end{array}$ & $\begin{array}{l}100-100=0 / \\
100 \%\end{array}$ & $100 \%$ get job security \\
\hline $\begin{array}{l}\text { 5.Extra med- } \\
\text { ical facilities }\end{array}$ & $\begin{array}{l}\text { Maintain with } \\
\text { laws and con- } \\
\text { sideration being } \\
\text { humanity 90\% }\end{array}$ & $\begin{array}{l}\text { sostly could not en- } \\
\text { lack of ability 10\% }\end{array}$ & $\begin{array}{l}95-10=85 \% \\
90-10=80 \%\end{array}$ & $\begin{array}{l}85 \% \text { get extra medical } \\
\text { facilities } 80 \% \text { do not }\end{array}$ \\
\hline $\begin{array}{l}\text { 6.Working } \\
\text { time in preg- } \\
\text { nancy }\end{array}$ & $\begin{array}{l}8.00 \text { AM - 5.00 } \\
\text { PM }\end{array}$ & $\begin{array}{l}8.00 \text { AM - } \\
5.00 \text { PM } \\
100 \%\end{array}$ & $100 \%$ & $\begin{array}{l}100 \% \text { get less working } \\
\text { time in pregnancy }\end{array}$ \\
\hline
\end{tabular}

Table 2: The comparison situation between local and foreign owned factories

In our country 5\% foreign owned and 95\% local owned factories are exist that's why the ratio are calculated from the data those are collected from field level by own. In this table, variables from table no 1.1 has considerate. This table is show the comparison between two kinds of factories for providing better facilities in recent time. Here, $5 \%$ is foreign owned investor and $95 \%$ is local owned investor factories.

\section{Ratio for providing facilities}

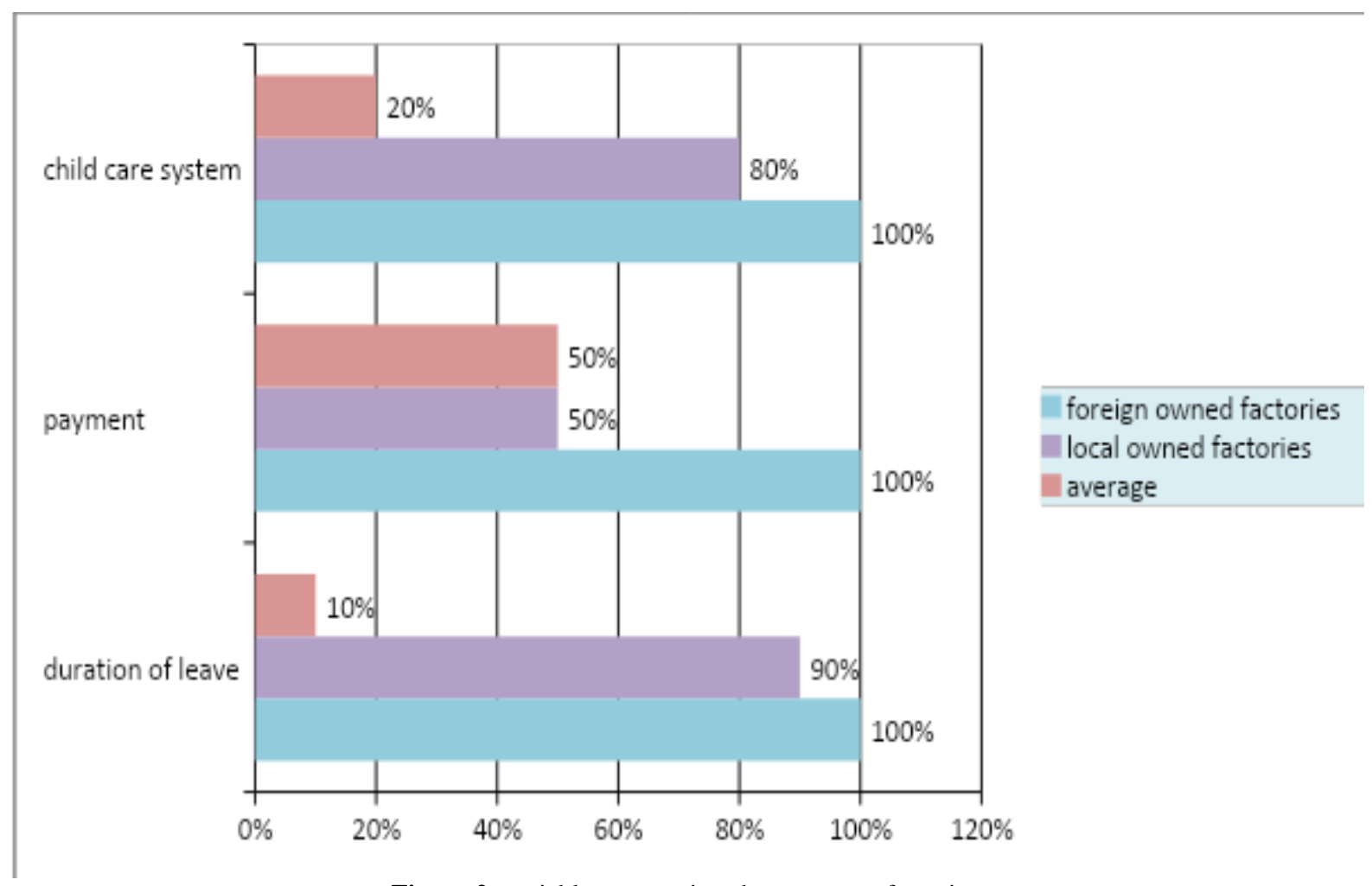

Figure 2: variables comparison between two factories. 
In this figure, the $90 \%$ female worker get leave facilities, $45 \%$ get advanced payment, $20 \%$ get after child birth facilities. This is the real situation in foreign owned factories. But in local owned factories: $90 \%$ get leave opportunity, $50 \%$ advanced payment, $20 \%$ get child care facilities, $10 \%$ get extra medical facilities. The job security is same in both factories.

From this observation, it is showing the foreign owned investor factories provide proper facilities rather than local factories. As a result, the workers are not satisfied and they hold the tendency to move in foreign owned investor factories. If the government could ensure the local investor factories to provide the proper facilities then this problem could be mitigated. This is important that local factories owner could provide facilities because lack of enough capital.

\section{FINDINGS}

Various studies have drawn attention to the deficiencies in RMG sector's maternity leave and cash payment system. This paper is trying to find out the real application of law in RMG sector. Some are following:

1. Foreign owned factories worker gets proper facilities (16 weeks maternity leave and advance payment, day care Centre).

2. The local owned factories worker gets mostly 3 months $/ 4$ months leave. They get 2 months advance payment before leave and 2 months payment after joining.

3. Most of the local owned factories workers do not get extra medical facilities like foreign owned factories worker get.

4. Discrimination are exist in Bengali factories (local owned) like using elevator, early leave, extra facilities for caring child etc.

5. Most of the garment female worker do not want share their experience because afraid of losing job (mostly in Bengali factories).

6. Most of workers have given up their job because of taking care of their new baby born.

7. Getting a job in foreign owned factories it is a desire of every single worker in Bengali factories because of proper facilities.

\section{RECOMMENDATION}

1. The first recommendation is that the government should make a proper factory registration list.

2. Government should ensure the facilities proving ability by Bengali factories owners.

3. Ensure that in every factory, there have worker unions.

4. Increase the maternity leave duration from 4 months to 6 months because of good caring the new born babies.

5. Ensure a day care system in every factory.

6. Ensure the proper advanced payment for every worker.

7. Ensure the accountability from factory owners about proving the facilities.

8. Make a equality to get child care system between stuff level and worker level female.

9. Increase the competitive situation between these two kinds of factories.

\section{CONCLUSION}

We have large scale female labor opportunity in RMG sector for our country. The proper facilities about maternity leave and payment system has been totally utilized by foreign owned investor factories and that is only $5 \%$. But the rest of $95 \%$ Bengali factories could not provide properly (from Wikipedia). The real situation is that $95 \%$ factories owner could not take a proper care about the application of rules which was published in 15 September, 2015. This problem can be mitigated by government by bringing these factories in competitive situation and another way is to proper application of existing Act and Laws with restriction. 


\section{REFERENCES}

Ahmed,R.S.(1991), “Garment Industry: A Quite Triumph” „Holiday, December.

Ahmed,M.N and M.S. Hossain(2006).” Future prospects of Bangladesh's RMG industry and the supportive policy Regime” , Mimeo, Bangladesh Bank, Dhaka.

Kamal,M.,Billah, M.M. and Hossain,s (2010), Labor unrest and Bangladesh Labor Act 2006: A study on Readymade Garment Factories in Gazipur” , Journal of Business and technology(Dhaka).

Rahman,M.H. and Siddiqui,S.A.(2015), “Female RMG worker: Economic contribution in Bangladesh” , International Journal of Research publication, volume 5.

Absar,S.S.(2001), “Problems surrounding wages: the readymade garments sector in Bangladesh” , Labor and management in development Journal, Volume-2.

Faruque,O., Islam, Md. R.(2014),” Cash Benefit Payment for Maternity leave: An analysis on some NGSs in Bangladesh” , Humane Resource Management Research, 4(1):5-12

Mia, Md. A. R., “Rights of women workers in the readymade garment (RMG) sector of Bangladesh” , Sonargaon University Journal, Vol.1, No.1.

Anam,R.L.(2008), "Inadequacies and variations of maternity leave policies throughout the world: special focus on Bangladesh” , BRAC University Journal, Vol.v,No.1,pp.93-98.

"The Bangladesh Labor Act-2006" (chapter 4) "Maternity Benefit" .

"Textile industry in Bangladesh" - Google search.

Sarker, Md. F.H.(2011), “History of Garment Industry in Bangladesh”, Daffodil International University, textile science, events ,trade and fair.

Google scholar.com 